\title{
FORUM
}

Submitted 21.09.2017. Approved 11.04.2018.

Evaluated by double blind review process.

DOI: http://dx.doi/10.12660/joscmv11n1p80-93

\section{INFLUENCE BETWEEN INDIVIDUAL ENTREPRENEURIAL ORIENTATION, SERVICE STRATEGY AND BUSINESS PERFORMANCE}

\begin{abstract}
In today's competitive business environment, the influence of strategies is directly linked to the demands of the market, particularly through individual performance, whether concerning customers or suppliers of products and services. The goal of this study was to investigate the influence between individual entrepreneurial orientation, service strategy and business performance. To that end we conducted a descriptive quantitative study with a sample of 250 respondents in the hospitality industry in Brazil. We used a conceptual model with hypotheses which we tested through the modelling of structural equations, using Smart PLS 3.0 software. The theoretical and practical implications obtained from our field research indicate that the latent variable Individual Entrepreneurial Orientation has a greater impact on service strategy, followed by a small influence of service strategy on business performance. For future research, we recommend investigating the relationship between individual entrepreneurial orientation and business performance.
\end{abstract}

KEYWORDS | Individual entrepreneurial orientation, service strategies, business performance, structural equations, hospitality.

\author{
Mercia Cristiley Barreto Viana \\ profamerciac@gmail.com
}

Kleber Cavalcanti Nóbrega

klebercnobrega@gmail.com

Lieda Amaral Souza

lieda2009@gmail.com

Universidade Potiguar, Natal, RN, Brazil 


\section{INTRODUCTION}

In today's fiercely competitive business environment, the services industry stands out when it comes to consumers' demands. The services industry is huge and it is considered as key for social development (Gronroos, 2009). According to Service Brazilian Support to Micro and Small Enterprises (Sebrae 2015), the services industry has grown across the country to branch out into various segments, unveiling new business horizons where some opportunities were explored and others expanded. In this respect, companies' performance depends on a number of factors, but the personal characteristics of the individuals who lead them are essential (Hill, Jones, \& Schilling, 2014). Therefore, theoretical and practical studies seek to understand the relationships and the degree of influence between the individual characteristics of managers, the service strategies they adopt and how both factors impact business performance.

Thus, competition indicates that the ability to innovate and develop new products and services becomes an even greater challenge to organizations, leading them to take risks and achieve a significant economic growth constituted by the opportunities developed both in the country and globally. Therefore, this article aims to investigate the influences related to individual entrepreneurial orientation (IEO), the adoption of service strategies and business performance. Our study covered services provided in the hospitality industry, a term used by Brotherton (1999) to designate those who host travelers by providing them with lodging and food in order to generate effects of entertainment. From this perspective, managers' mission is to turn the needs of customers into the comfort and warmth of a personalized hospitality for each individual (Camargo, 2015).

However, when Bolton and Lane (2012) replicated a study on Entrepreneurial orientation (EO) at the individual level, of the five EO dimensions, they only found three: innovation capacity, proactivity and risk-taking. Therefore, organizations are increasingly interested in initiating their activities with well-planned, well-defined service strategies, seeking a competitive edge through innovation valuable to the client - in other words, service strategy emerges as the guiding principle for proposing goods and services, adding value to the firm's main product (Gronroos, 2009; Johnston \& Clark, 2010; Lovelock \& Wright, 2001; Nóbrega, 2013). Given the above, the study's main question emerges as follows: What are the influences between Individual Entrepreneurial Orientation, Service Strategy and Business Performance?

\section{THEORETICAL REFERENCE}

\section{Individual Entrepreneurial Orientation}

Individual Entrepreneurial Orientation(IEO) emerged with the in-depth investigation conducted by Lumpkin and Dess (1996) on studies of entrepreneurship (ES) in organizations. Bolton and Lane (2012) examined studies on EO and found that only organizations had been surveyed. Therefore, human individual participation in organizations was not being addressed by research. Thus, they developed a research tool and used it with 1,100 MBA students in the USA in order to test the dimensions studied by Lumpkin and Dess (1996) at the individual level. The former found that the proactivity dimension resembles competitive aggressiveness, thus allowing to merge these into a single dimension. Also noteworthy, of the 52 factors used in the study, only 10 were confirmed as characteristics of individuals in the three dimensions (i.e., risk-taking, innovation capacity and proactivity).

The characteristics of individuals are directly related to their involvement with the organization (Levenburg \& Schwarz, 2008; Raposo, Paço, \& Ferreira, 2008; Harris \& Gibson, 2008). Entrepreneurial actions, along with individual characteristics, are highlighted by individuals' personality and attitude which can be affected by external and social influences (Zahra, 2005; Lumpkin \& Dess, 1996). The authors have shown that EO can impact company performance both directly and indirectly, depending on the different environments in which they operate. Hughes and Morgan (2007) believe that the different ways of describing entrepreneurial orientation may have caused divergent results concerning the construct studied with organizational performance, since a few authors found positive correlations, while others found none (Bolton \& Lane, 2012; Hughes \& Morgan, 2007; Lumpkin \& Dess, 1996; Miller, 1983; Wiklund \& Shepherd, 2005).

Stewart, Castrogiovanni, and Hudson (2016) consider that if the characteristics of the entrepreneur (individual) are associated with an entrepreneurial orientation (organization), this combination can achieve gains regarding the strategies adopted by the firm. Consequently, the stream of future profits of strategic operations seek prospective business opportunities, observing competitors' moves (Lumpkin $\&$ Dess, 1996). Given the above, our theoretical proposition was developed on solid scientific foundations. Therefore, we raise the following hypothesis: H1 - Individual entrepreneurial orientation positively influences the adoption of the service strategy. 


\section{Service Strategy}

Service strategies have been part of various business activities since the very beginning of business administration until contemporary business adminis- tration. Therefore, measuring them or choosing the best strategic alternatives is not an easy task. Exhibit 1 shows the interfaces between the main theoretical models on Service Strategy.

\section{Exhibit 1: Interfaces between the main theoretical models on Service Strategy}

\begin{tabular}{|c|c|}
\hline Variables & Authors \\
\hline Access & Corrêa and Caon (2010); Nóbrega (2013) \\
\hline Attitude & Johnston and Clark (2010) \\
\hline Capacity & Lovelock and Whight (2001) \\
\hline Competence & $\begin{array}{l}\text { Corrêa and Caon (2010); Hoffman (2009); Lovelock and Whight (2001); Nóbrega (2013); } \\
\text { Teboul (1999); Zhang and Bruning (2011) }\end{array}$ \\
\hline Communication & Corrêa and Caon (2010); Heskett (2002); \\
\hline Competitors & $\begin{array}{l}\text { Corrêa and Caon (2010); Fitzsimmons (2010); Groonros (2009); Jhonston and Clark (2010); } \\
\text { Lovelock and Whight (2001); Nóbrega (2013); Heskett (2002); Contador and Meireles } \\
\text { (2004); Zhang and Bruning (2011). }\end{array}$ \\
\hline Reliability & $\begin{array}{l}\text { Groonros (2009); Teboul (1999); Contador and Meireles (2004); Slack and Lewis (2003); Ge- } \\
\text { bauer (2005); }\end{array}$ \\
\hline Comfort & Corrêa and Caon (2010); Heskett (2002); \\
\hline Knowledge & Corrêa and Caon (2010); Groonros (2009); Nóbrega (2013); \\
\hline Consistency & Corrêa and Caon (2010); Victorino et al (2005); \\
\hline Creativity & Slack and Lewis (2003); Gebauer (2005); Zhang and Bruning (2011) and Ketchen et al (2007); \\
\hline Performance & $\begin{array}{l}\text { Heskett (2002); Slack and Lewis (2003); Gebauer (2005); Zhang and Bruning (2011) and } \\
\text { Ketchen et al (2007) }\end{array}$ \\
\hline Differentiation & $\begin{array}{l}\text { Corrêa and Caon (2010); Fitzsimmons (2010); Groonros (2009); Hoffman (2009); Jhonston } \\
\text { and Clark (2010); Lovelock and Whight (2001); Nóbrega (2013); Zeithaml (2012); Slack and } \\
\text { Lewis (2003); }\end{array}$ \\
\hline Service Availability & $\begin{array}{l}\text { Lovelock and Whight (2001); Nóbrega (2013); Heskett (2002); Slack and Lewis (2003); Con- } \\
\text { tador and Meireles (2004); Victorino et al (2005); }\end{array}$ \\
\hline Esthetics & Corrêa and Caon (2010); \\
\hline Flexibility & Corrêa and Caon (2010); Grönroos (2009); Slack and Lewis (2003); \\
\hline Integrity & Corrêa and Caon (2010); Jhonston and Clark (2010); \\
\hline
\end{tabular}




\begin{tabular}{|c|c|}
\hline Cleanliness & Corrêa and Caon (2010); Jhonston and Clark (2010); \\
\hline Opportunity & $\begin{array}{l}\text { Corrêa and Caon (2010); Groonros (2009); Jhonston and Clark (2010); Lovelock and Whight } \\
\text { (2001); Nóbrega (2013); Heskett (2002); Contador and Meireles (2004); Slack and Lewis } \\
\text { (2003); Victorino et al (2005); Zhang and Bruning (2011); }\end{array}$ \\
\hline $\begin{array}{l}\text { Deadline } \quad \text { (response } \\
\text { time) }\end{array}$ & Contador and Meireles (2004); \\
\hline Price (cost) & Corrêa and Caon (2010); Contador and Meireles (2004); Groonros (2009); Zeithaml (2012); \\
\hline Perceived Quality & Corrêa and Caon (2010); Groonros (2009); Zeithaml (2012); \\
\hline Quality of goods & $\begin{array}{l}\text { Corrêa and Caon (2010); Contador and Meireles (2004); Slack and Lewis (2003); Gebauer } \\
\text { (2005); }\end{array}$ \\
\hline Security & Corrêa and Caon (2010); Jhonston and Clark (2010); \\
\hline Speed & Corrêa and Caon (2010); Nóbrega (2013); Slack and Lewis (2003); \\
\hline
\end{tabular}

In this context, studies say that individual entrepreneurs are more likely to show innovation capacity. In contrast, individuals who work in a more competitive environment tend to be more cautious and follow field/industry rules (Zhan, Bruning, 2011). Thus, it is necessary to develop more than one "weapon" or service strategy for simultaneous use through the following characteristics: competitiveness through the price of goods and services; customer care; image; or delivery deadline (Contador \& Meireles, 2004). According to Johnston and Clack (2010), service strategies must be appropriate and continuous, since companies become aware that by improving the service they provide they will achieve greater gains and, therefore, a better business performance. According to a service strategy conceptualized by Victorino, Verma, Plaschka, and Dev (2005), the factor that influences hotel industry services most is innovation, which is attractive to clients while facilitating business management processes, thus improving business performance. Thus we raise the following hypothesis: $\mathrm{H} 2$ - Service strategy has a positive influence on business performance. Given the above, service strategy is the way an organization sees itself and sets about offering services to its clients (Nóbrega, 2013, p.33).

\section{Business Performance}

Business performance is usually measured by financial variables. However, obtaining that information is not an easy task; in fact, it is a difficulty that may render a study invalid (Perin \& Sampaio, 2004). Therefore, we analyzed firms' strategic decision-making, as well as their marketing and financial performance measures and operational indicators (Vij \& Bedi, 2016). Thus, the present study uses two perspectives related to business performance: Balanced Scorecard (BSC) and CSL. BSC's dimensions are as follows: a) Financial: Economic Value Added (EVA), Return on Investment (ROI) and Earnings Before Interest, Taxes, Depreciation and Amortization (EBTIDA); b) customer: customer satisfaction and retention; c) internal processes: operations, innovation and after-sales service; d) learning and growth: training and employee satisfaction (Kaplan \& Norton, 1997). According to Zattar, Silva, and Silva (2014), BSC is a model that is able to convey the company's raison d'être by means of its strategy and of performance indicators related to effective strategic management. The service-profit chain (SPC) is based on financial performance, which is associated with a "mirror effect" between employee and customer satisfaction and loyalty (Heskett, 2002). 
Figure 1: Model Service Profit Chain (CSL) - adapted (HESKETT, 2002)

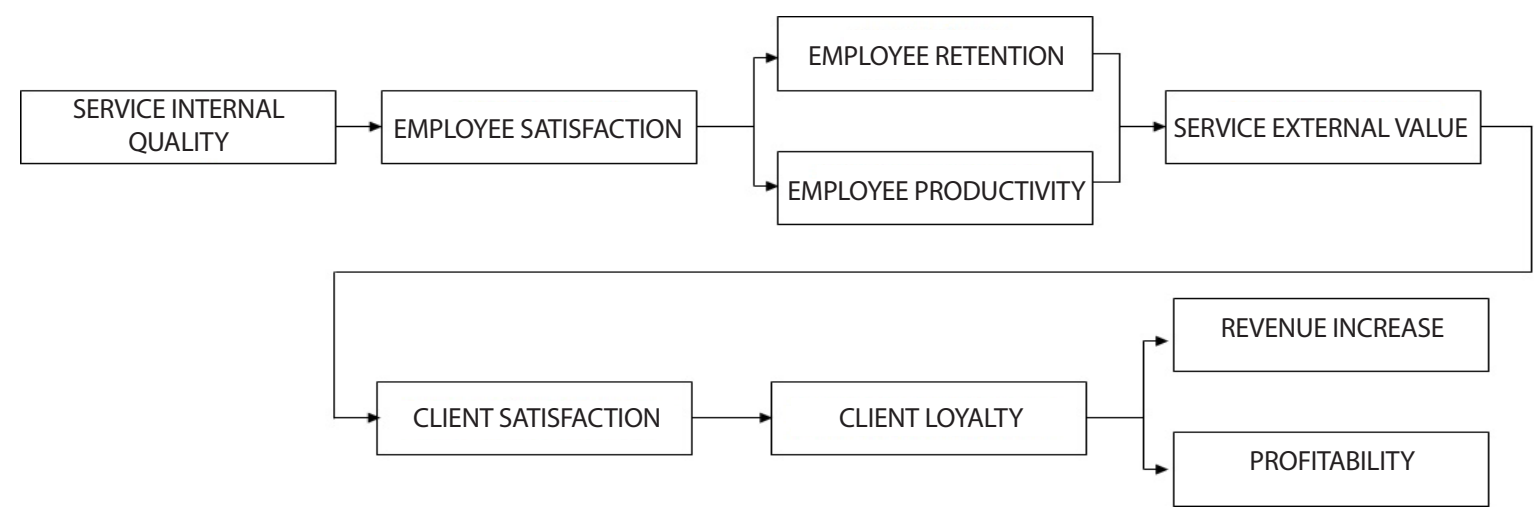

\section{METHODOLOGICAL PROCEDURES}

The present study is descriptive and exploratory in that it addresses the combination of three latent variables (i.e., IEO, service strategy and perception of business performance) to propose a conceptual model. With regard to our approach to the problem studied, data collected were treated quantitatively. For our review of the literature on individual entrepreneurial orientation, service strategy and business performance, we searched a few databases, such as: Emerald, Scielo and Scopus. Thus, we searched theses, dissertations, books, among others. We chose a statistical technique consistent with our initial purposes, considering the types of relationship between theory and data collection, as well as the nature of the variables. In structural equation modeling, one of the basic characteristics is the possibility to test the causal relationship between a set of variables.

The population consisted of 250 Brazilian entrepreneurs or managers of both genders (male or female) aged 18 to 65 or older, in the hospitality industry (bars, hotels and restaurants) in Brazil. Data were collected from August to December 2016. The sampling was determined by accessibility and convenience, rather than probabilistic sampling techniques in the hospitality industry. For sample calculation, we followed Hair Jr et al. (2005), who say the number of respondents must be 5 to 10 times the number of variables of the largest construct or latent variable. In our case, the largest construct has 25 variables; therefore, the sample consisted of 250 respondents. We used partial least squares structural equation modeling (PLC-SEM) with Smart PLS 3.0 software. Below, the meaning of abbreviations presented in Figure 2: IEO - Individual Entrepreneurial Orientation; SS - Service Strategy; and BP - Business Performance. This multivariate statistical analysis method was the most adequate to our study as it allows investigating how well predictors can explain the dependent variable (criterion) and which predictor variable is the most important. Regression, too, could be used for these purposes, though one must consider that there can be more than one dependent variable in a single model (Maruyama, 1998).

\section{Figure 2: Hypothesis Model}

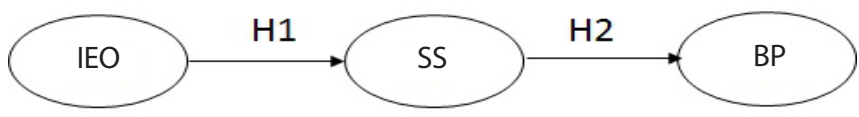

The conceptual model we propose includes latent variables and observable variables. Thus, we used partial least squares which determine the latent variable that gets the greatest number of arrows or a greater number of predictors by means of the causal relationship (a path coefficient between latent and observed variables) studied (Ringle, Silva, \& Bido, 2014).

The hypotheses we identified in the literature were: $\mathrm{H} 1$ - Individual entrepreneurial orientation positively influences the adoption of the service strategy; and H2 - Service strategy has a positive impact on business performance. 


\section{RESULTS: PRESENTATION AND ANALYSIS}

In this section, we present the analyses we carried out in this study using Smart PLS 3.0 software. Figure 3 shows the conceptual model we proposed for the constructs.

Figure 3: Conceptual model proposed (Smart PLS)

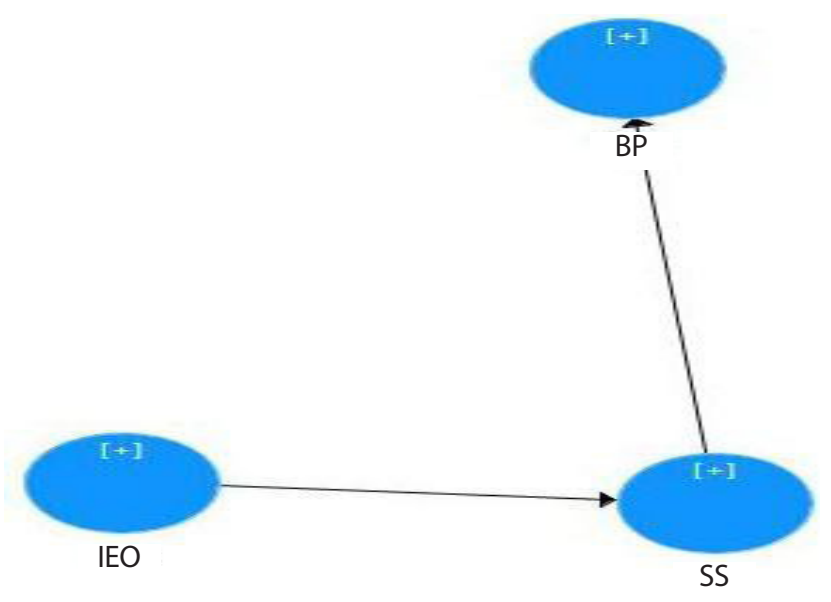

Source: Search data (2016).

\section{Sample Profile}

The sample consisted of 250 respondents of our online questionnaire, thus meeting the minimum required for the sample, at a confidence level of $97.5 \%$ and with a sampling error of $2.5 \%$, as shown in Exhibit 2.

\section{Exhibit 2: Sample Profile}

\begin{tabular}{c|l|r|r}
\hline \multicolumn{2}{c|}{ DESCRIPTION } & QUANTITY & PERCENTUAL \\
\hline \multirow{4}{*}{ INDUSTRY SECTOR } & Hotels & 55 & $22.00 \%$ \\
& Bars & 53 & $21.20 \%$ \\
& Restaurants & 122 & $48.80 \%$ \\
& Bars/ restaurants & 20 & $8.00 \%$ \\
& Total & 250 & $100.00 \%$ \\
\hline \multirow{5}{*}{ GENDER } & Male & 148 & $59.20 \%$ \\
& Female & 100 & $40.00 \%$ \\
& Male / Female & 2 & $0.80 \%$ \\
& Total & 250 & $100.00 \%$ \\
\hline \multirow{5}{*}{ AGE } & 18 to 25 & 51 & $20.40 \%$ \\
& 26 to 35 & 115 & $46.00 \%$ \\
& 36 to 49 & 63 & $25.20 \%$ \\
& 50 or older & 21 & $8.40 \%$ \\
& Total & 250 & $100.00 \%$ \\
\hline \multirow{5}{*}{ EDUCATION } & Primary Education & 20 & $8.00 \%$ \\
& Secondary School & 123 & $49.20 \%$ \\
& Higher Education & 93 & $37.20 \%$ \\
& Graduate Education & 14 & $5.60 \%$ \\
& Total & 250 & $100.00 \%$ \\
\hline
\end{tabular}




\begin{tabular}{l|l|r|r}
\hline & Up to 2 years & 65 & $26.00 \%$ \\
SERVICE TIME & 3 to 6 years & 88 & $35.20 \%$ \\
& 7 to 10 years & 52 & $20.80 \%$ \\
& Up to 10 years & 45 & $18.00 \%$ \\
& Total & 250 & $100.00 \%$ \\
\hline
\end{tabular}

Source: Research data (2016).

\section{Data processing}

Table 1 shows the Variance Inflation Factor (VIF), which was 1.00 .

Table 1: Variance Inflation Factor (VIF)

\begin{tabular}{l|l|l|l}
\hline & BP & SS & IEO \\
\hline BP & & & \\
SS & 1.000 & & \\
IEO & & 1.000 & \\
\hline
\end{tabular}

Source: Research data (2016).

Our study had a mean estimated VIF of less than 3.3. According to Kock (2015), the value of VIF should be less than 3.3, corroborating Ringle et al. (2014), to whom variables with a small multicollinearity index generate reliable results. Tables 2 and 3 show the composite reliability and Cronbach's alpha.

Table 2: Compound Reliability

\begin{tabular}{l|l}
\hline BP & 0.945 \\
SS & 0.925 \\
IEO & 0.835 \\
\hline
\end{tabular}

Source: Research data (2016).

\section{Table 3: Cronbach's Alpha}

\begin{tabular}{l|l}
\hline BP & 0.922 \\
SS & 0.907 \\
IEO & 0.765 \\
\hline
\end{tabular}

Source: Research data (2016).

Table 4: Factor loading after model adjustment

\begin{tabular}{l|l|l|l}
\hline & BP & SS & IEO \\
\hline BP-01 & 0.911 & & \\
\hline BP-02 & 0.941 & & \\
\hline BP-03 & 0.898 & & \\
\hline BP-04 & 0.849 & & \\
\hline SS-07 & & 0.714 & \\
\hline SS-09 & & 0.778 & \\
\hline SS-12 & & 0.745 & \\
\hline SS-14 & & 0.725 & \\
\hline SS-22 & & 0.813 & \\
\hline SS-23 & & 0.817 & \\
\hline SS-24 & & 0.839 & \\
\hline SS-25 & & & 0.786 \\
\hline IC-04 & & & 0.579 \\
\hline IC-07 & & & 0.712 \\
\hline PRO-08 & & & 0.799 \\
\hline PRO-09 & & & 0.842 \\
\hline PRO-10 & & & \\
\hline
\end{tabular}

Source: Research data (2016).The results presented in Table 4 show the variables that remained after the adjustments. The 
AVE must have acceptable results. Therefore, in order for the desired results to be adequate, adjustments were made to the model. The variables excluded from the study were: RST-01, RST-02, RST-03, IC-05, IC-06, SS-01, SS-02, SS-03, SS-05, SS-06, SS-08, SS-10, SS11, SS-13, SS-15, SS-16, SS-17, SS-18, SS-19, SS-20, and SS-21. Table 4 shows the variables that remained after the adjustment. It shows that most of the data show a factor loading equal to or greater than 0.7 . However, results for the variables IC-04 and IC-07 were smaller than the established standard.
Therefore, despite the loads for variables IC-04 and IC-07 are small, these variables should not be excluded since they belong to a construct that has been validated by previous research, and because they have no AVE-related problem.

To be acceptable, the threshold for the average variance extracted (AVE) must be $\geq 0.5$ (Bido, Silva, Souza, \& Godoy, 2010; Kock, 2015a). The latent variables were well explained by the variables observed, as shown in Table 5, therefore, all AVE values are within acceptable limits.

\section{Table 5: Average Variance Extracted (AVE) after adjustment}

\begin{tabular}{ll}
\hline & AVE \\
\hline BP & 0.810 \\
SS & 0.606 \\
IEO & 0.508 \\
\hline
\end{tabular}

Source: Research data (2016).

Discriminant validity is an additional component in the model validation process. By comparing the individual AVEs in Table 5 with the AVE square roots for each construct in Table 6, we found that the AVE values were smaller than the square root. Thus, data proved acceptable, without interference by the other variables, and the model's discriminant validity was confirmed (Kock, 2015).

\section{Table 6: Discriminant validity}

\begin{tabular}{llll}
\hline & BP & SS & IEO \\
\hline BP & 0.900 & & \\
SS & 0.336 & 0.778 & \\
IEO & 0.081 & 0.378 & 0.713 \\
\hline
\end{tabular}

Source: Research data (2016).

Note: The square root of the average variance extracted (AVEs) is on the diagonal.

Table 7 shows that $\mathrm{R}^{2}$ values for this model after regression are 0.521 and 0.215 for a $\mathrm{p}<0.001$. In the field of social and behavioral sciences, $\mathrm{R}^{2}=2 \%$ is of small effect, $R^{2}=13 \%$ is of medium effect and $R^{2}=$
26\%, of great effect (Cohen, 1988). Therefore, they were explained with small and medium effect for the model proposed.

Table 7: $\mathbf{R}^{2}$ coefficient

\begin{tabular}{lll}
\hline & $\mathrm{R}^{2}$ & $\mathrm{R}^{2}$ adjusted \\
\hline BP & 0.113 & 0.109 \\
SS & 0.143 & 0.140 \\
IEO & & \\
\hline
\end{tabular}

Source: Research data (2016). 
$\mathrm{R}^{2}$ values for this model after the regression are 0.109 and 0.140 for a $p<0.001$. Though these are not poor results, a good explanation of the construct in the model requires a minimum 0.4973 . However, all constructs in the model have at least 4 variables, thus contributing to a significant solution (Cohen, 1988; Reinartz, Haenlein, \& Henseleret, 2009). Table 8 shows that the path coefficients have positive values closer to +1 , which is considered acceptable to validate the hypotheses.

Table 8: Path coefficient (Beta)

\begin{tabular}{llll}
\hline & BP & SS & IEO \\
\hline BP & & & \\
SS & 0.336 & & \\
IEO & & 0.378 & \\
\hline
\end{tabular}

Source: Research data (2016).

The Cohen factor $\left(\mathrm{f}^{2}\right)$ is analyzed according to the size of the effect it provides for the model path; thus, with regard to construct effects, 0.02 is considered of small, 0.15 of medium and 0.35 of great effect in social sciences. This means that the variables chosen for each construct are the most adequate for the fit of the model. As shown in Table 9, factor 0.287 is of medium effect; however, factor 0.626 is of great effect for the path, according to the parameters used (Hair Jr. et al., 2014). Therefore, all indexes were accepted for the model path.

\section{Table 9: Cohen factor $\left(f^{2}\right)$}

\begin{tabular}{llll}
\hline & BP & SS & IEO \\
\hline BP & & 0.626 & \\
SS & & & 0.472 \\
IEO & 0.287 & & \\
\hline
\end{tabular}

Source: Research data (2016).

Table 10 shows values above the established threshold of 1.96 (Hair Jr et al., 2014), therefore, the paths between the constructs are significant for the structural model adjusted.

\section{Table 10: t-value}

\begin{tabular}{ll}
\hline & $t$-value \\
\hline IEO $->$ SS & 7.177 \\
SS $->$ BP & 5.337 \\
\hline
\end{tabular}

Source: Research data (2016). 


\section{DISCUSSION OF RESULTS}

Figure 4 shows the adjusted indices in the model for the latent variable (IEO) and the observed variables (SS and BP).

\section{Figure 4: Hypothesis Model Adjusted - Smart PLS}

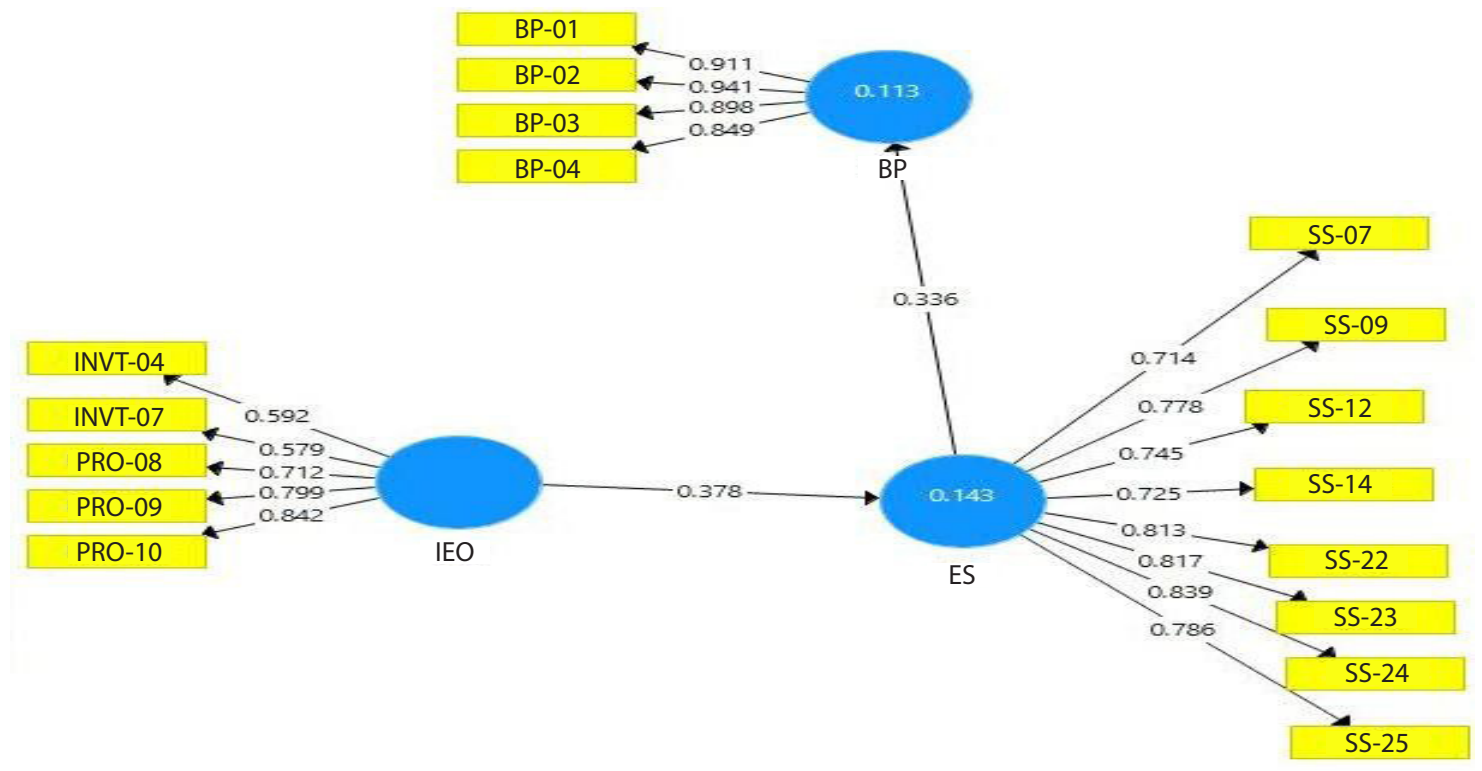

Figure 5 shows the Student's t coefficients.

\section{Figure 5: Hypothesis Model with Student's " $t$ " coefficient}

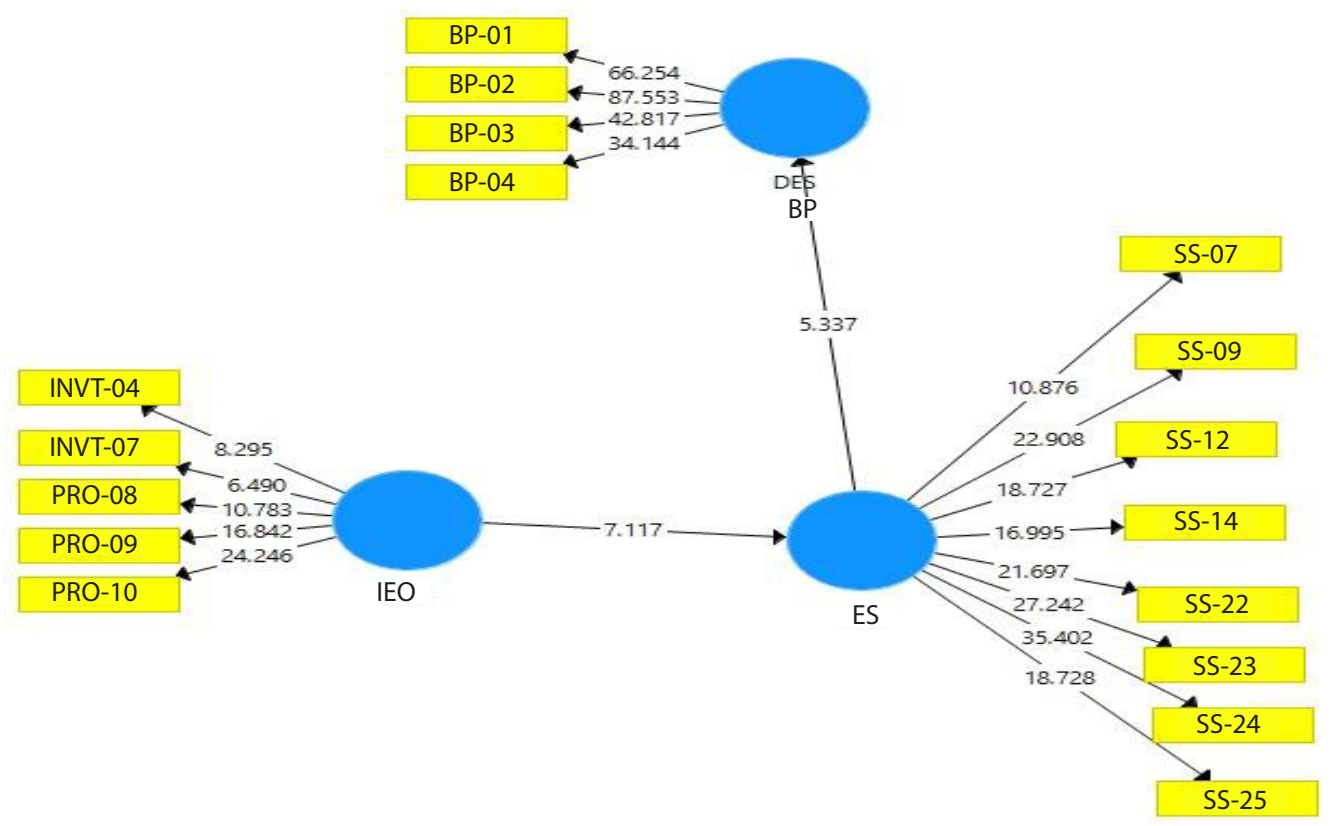

Table 11 summarizes the results for the model after the adjustment, using partial least squares structural equation modelling, which harmonizes the analysis and assessment of the hypotheses we proposed in this study. 
Table 11: Summary of Data after Adjustment

\begin{tabular}{|c|c|c|c|c|c|}
\hline & $\mathrm{BP}$ & SS & IEO & Criteria & Authors \\
\hline VIF & 1.000 & 1.000 & - & $\mathrm{VIF}<3.33$ & Ringle et al. (2014) \\
\hline AVE & 0.810 & 0.606 & 0.508 & AVE $>0.50$ & $\begin{array}{l}\text { Bido et al. (2010) Kock } \\
\text { (2015)b }\end{array}$ \\
\hline Composite Reliability & 0.945 & 0.925 & 0.835 & $C C>0.70$ & $\begin{array}{l}\text { Bido et al. (2010) Hair Jr et } \\
\text { al. (2014) }\end{array}$ \\
\hline Cronbach's Alpha & 0.922 & 0.907 & 0.765 & $A C>0.70$ & Bido et al. (2010) \\
\hline Discriminant Validity & 0.900 & 0.778 & 0.713 & $\begin{array}{l}\text { AVES square roots }>\text { than the } \\
\text { correlations between the } \\
\text { constructs }\end{array}$ & $\begin{array}{l}\text { Kock (2015) } \\
\text { Hair Jr et al. (2014) }\end{array}$ \\
\hline$R^{2}$ & 0.113 & 0.143 & - & $\begin{array}{l}R^{2}=26 \% \\
R^{2}(\text { mean })=14 \%\end{array}$ & $\begin{array}{l}\text { Cohen (1988) Reinartz et } \\
\text { al. (2009) }\end{array}$ \\
\hline $\mathrm{R}^{2}$ adjusted & 0.109 & 0.140 & - & $\begin{array}{l}R^{2}=26 \% \\
R^{2}(\text { mean) }=14 \%\end{array}$ & $\begin{array}{l}\text { Cohen (1988) Reinartz et } \\
\text { al. (2009) }\end{array}$ \\
\hline
\end{tabular}

Exhibit 3 shows that the hypotheses were analyzed and confirmed. Table 8 shows the path index found. Thus, our study confirmed hypothesis H1, which postulated that individual entrepreneurial orientation positively influences the adoption of the service strategy, corroborating Stewart et al. (2016), who say that if the characteristics of the entrepreneur (individual) are associated with an entrepreneurial orientation (organization), this combination can achieve gains regarding the strategies adopted by the firm. On the other hand, we also confirmed hypothesis $\mathrm{H} 2$, which postulated that service strategy positively influences business performance, corroborating Victorino et al. (2005) who say that the factor that influences hotel industry services most is innovation, which is attractive to clients while facilitating business management processes, thus improving business performance.

\section{Exhibit 3: Hypotheses Results}

\begin{tabular}{l|l|l|l}
\hline Hypothesis & Relationship & Path Coefficient & Results \\
\hline $\mathrm{H} 1$ & IEO influences the adoption of service strategy. & 0.336 & Not rejected \\
\hline $\mathrm{H} 2$ & Service strategy influences business performance. & 0.378 & Not rejected \\
\hline
\end{tabular}

The values found for the adjusted $\mathrm{R}^{2}$ coefficient show that the business performance and service strategy constructs have a small explanatory power for the model proposed, since they were, respectively, 0.109 and 0.143 - i.e., about $11 \%$ and $15 \%$, which are poor indicators. However, even though the values found are below the parameter established by the literature, the hypotheses were not rejected because they are statistically significant, consistent with what the study proposes, and show an influence relationship between the constructs.

The IEO construct helps explain the model proposed, though to a lower degree. While its path co- efficient is not high, the hypothesis is confirmed, since the construct has been validated by Bolton and Lane (2012). Hypothesis H1 is also confirmed, however, by presenting a medium path coefficient, thus corroborating the studies of Lumpink and Dess (2001) according to which these personality factors (innovativeness and proactivity) can influence organizations - just like, one might argue, proactivity can arise from extraversion, need for realization and openness to experience; it can also be influenced by extraversion, internal control and consciousness. 
Other researchers, such as Covin and Slevin (1989), argue that there is a mix of variables in studies on entrepreneurs' individual characteristics; however, the IEO-organization relationships are confirmed. Curiously, although risk-taking is a relevant characteristic of managers, we found no significant result for it in our study; we removed all analytical variables from the model since their coefficients were not sufficient to justify their permanence, corroborating the study of Zahra (2005) according to which managers often run firms on their own, without paying attention to risks coming from the market. Businesses that are run by experienced managers aim to acquire, assimilate and transform other financial resources into exceptional organizational resources, as well as human capital to support both family and business growth needs (Yong \& Panikkos, 2010).

Service strategy has a small influence on business performance, with a path index of 0.336 . Although its $\mathrm{f}^{2}$ is of small effect for the model path, it remains a matter of discussion, corroborating the study of Johnston and Clark (2010), service strategies must be appropriate and continuous, since companies become aware that by improving the service they provide they will achieve greater gains and, therefore, a better business performance.

According to the findings of this study, which consisted of investigating the influences between individual entrepreneurial orientation, service strategy and business performance, there are such influences between the constructs in the model proposed, although the indicators have a small explanatory power. Business performance was the construct that was best represented through our data, showing an influence by the adoption of a good service strategy, which therefore improves business performance, corroborating the study of Vij \& Bedi, (2016), according to which it is necessary to analyze firms' strategic decision-making, as well as their marketing and financial performance measures and operational indicators. However, entrepreneurial individual orientation shows how significant service strategy is, and data indicate that individual characteristics (innovativeness and proactivity) positively influence the adoption of the service strategy. This corroborates the study of Zhang \& Bruning (2011), according to which entrepreneurs working in an environment with many growth opportunities are more likely to show innovation capacity. In contrast, individuals who work in a more competitive environment tend to be more cautious and follow field/industry rules

\section{CONCLUSIONS}

The goal of this study was sought through the proposed model, which allows investigating the influences between the constructs. We found that the IEO construct has a greater influence on service strategy, followed by a small influence between service strategy and business performance. This corroborates the study of Yong and Panikkos (2010) according to which entrepreneur individual characteristics appear in several critically important roles in terms of behavior and company performance.

This study provides contributions such as the model we propose for the influence relationship between the constructs presented, since no similar conceptual model was found in the literature reviewed that addressed the industry we investigated. Another relevant finding was that manager individual characteristics positively influence the adoption of service strategies and, therefore, business performance; in other words, based on our theoretical framework, our results suggest that organizations should choose their managers based on individual characteristics that are relevant to the model of strategic management adopted, and observe business performance through financial data.

The theoretical implications are related to the fact that only three latent variables (service strategy, IEO and business performance) were considered. One limitation is that the IEO influence on business performance was not addressed in the model proposed. Another theoretical implication was the limitation regarding national and international articles, books and electronic databases. Thus, we recommend further research to investigate the relationship between IEO and business performance. We also recommend further research aimed at replicating the results obtained in this study in other contexts, i.e., testing the structural model proposed here in other industries. Another recommendation is to determine whether the influences between the constructs service strategy and business performance (SS->BP) can generate financial gains for organizations. Therefore, we may conclude that more studies are necessary to understand, explain and analyze both the theoretical and practical aspects of the influences between the constructs IEO, service strategy and business performance. 
As a managerial implication of this study, we recommend pursuing further insights into IEO in the services industry in Brazil, as well as the development of good practices for the hospitality industry. On the other hand, a better understanding of IEO dimensions can help researchers explore further the influences between the constructs studied and other factors of interest.

The findings of this study are scientific, and the study helped to advance the knowledge about individual entrepreneurial orientation, service strategies adopted and the perception of managers regarding business performance in the hospitality industry in Brazil. It also helped explain and disseminate advanced statistical techniques and analyzes such as structural equation modelling, which are still scarce in management research published in Brazil. It is worth noting that the study was conducted with 250 Brazilian managers in a particular industry (hospitality) and their individual entrepreneurial characteristics were identified using an instrument that has been validated in the United States by Bolton and Lane (2012).

\section{NOTE FROM THE EDITOR}

This article was presented at the XX Simpósio de Administração da Produção, Logística e Operações Internacionais in 2017.

\section{REFERENCES}

Bido, D. S., Silva, D., Souza, C. A., \& Godoy, A. S. (2010). Mensuração com indicadores formativos nas pesquisas em administração de empresas: Como lidar com a multicolinearidade entre eles. Administração: Ensino e pesquisa, 11(2), 245-269.

Bolton, D., \& Lane, M. (2012). Individual entrepreneurial orientation: development of a measurement instrument. Education Training, 54(2-3), 219-233.

Brotherton, B. (1999). Towards a definitive view of the nature of hospitality and hospitality management. International Journal of Hospitality Management Contemporany, 11(4), 165-173.

Camargo, L. O. (2015). Os intersticios da Hospitalidade. Revista Hospitalidade, 12, 42-70.

Cohen, J. (1988). Statistical power analysis for the behavioral sciences. New York: Psychology Press.

Contador, J. C., \& Meireles, J. L. (2004). Modelo de campos e armas de competição. ENEGEP, 25-41.
Covin, G., \& Slevin, D. (1989). Strategic management of small firms in hostile and benign environments. Strategic Management Journal, 10(1), 75-87.

Fitzsimmons, J., \& Fitzsimmons, M. (2014). Administração de Serviços: Operações estratégicas e tecnologia de informações. São Paulo: Bookman.

Gronroos, C. (2009). Marketing: Gerenciamento e serviços. Rio de Janeiro: Elsevier.

Hair Jr, J. F., Anderson, R. E., TATHAM, R. L., \& BLACK, W. C. (2005). In Fundamentos de métodos de pesquisa em administração, J. F. Hair, B. Babin, A. H. Money, \& P. Samouel (pp. 25-50). Porto Alegre: Bookman.

Hair Jr, J. J., Sarstedt, M., Hopkins, L., \& Kuppelwieser, V. G. (2014). Partial least squares structural equation modeling (PLS-SEM) an emerging tool in business research. Europe Business Review, 26(2), 106-121.

Harris, M. L., \& Gibson, S. (2008). Examining the entrepreneurial attitudes of US business students. Education \& training, 50(7), 568-581.

Heskett, J. (2002). Lucro na prestação de serviços. Rio de Janeiro: Campus.

Hill, C. W., Jones, G. R., \& Schilling, M. A. (2014). Strategic management: theory: An integrated approach. Stanford, CT: Cengage Learning.

Hughes, M., \& Morgan, R. (2007). Deconstructing the relationship between entrepreneurial orientation and business performance at the embryonic stage of firm growth. Industrial Marketing Management, 36(5), 651-661.

Johnston, R., \& Clark, G. (2010). Administração de operações de serviço. São Paulo: Atlas.

Kaplan, R. S., \& Norton, D. P. (1997). A estratégia em ação: Balanced Scorecard. Rio de Janeiro: Campus.

Kock, N. (2015a). Common method bias in PLS-SEM: A full collinearity assessment aproach. International Journal of e-collaboration, 11(4), 1-10.

Kock, N. (2015b). WarpPLS 5.0: User Manual. Laredo: Scriptwrap.

Levenburg, N. M., \& Schwarz, T. V. (2008). Entrepreneurial orientation among the youth of India the impact of culture, education and environment. Journal of Entrepreneurial, 17(1), 15-35.

Lovelock, C., \& Wright, L. (2001). Serviços: Marketing e gestão. São Paulo: Saraiva.

Lumpkin, G., \& Dess, G. (1996). Clarifying the entrepreneurial orientation construct and linking it to performance. The Academy of management review, 21(1)135-172.

Maruyama, G. M. (1998). Basics of structural equation modeling. London: Sage Publications. 
Miller, D. (1983). The correlates of entrepreneurship in three types of firms. Management Science, 29(7), 770-791

Nóbrega, K. (2013). Falando de serviços: Um guia para compreender e melhorar os serviços em empresas e organizações. São Paulo: Atlas.

Perin, M. G., \& Sampaio, C. H. (2004). Orientação para o mercado, porte empresarial e performance. RAE-Revista de Administração de Empresas, 44(3), 76-88.

Raposo, M., Paço, A. D., \& Ferreira, J. (2008). Entrepreneur's profile: A taxonomy of attributes and motivations of university studies. Journal of small business, 15(2), 405-418.

Reinartz, W., Haenlein, M., \& Henseler, J. (2009). An empirical comparison of the efficacy of covariance-based and variance-based SEM. International Journal of research in Marketing, 26(4), 332-344.

Ringle, C. M., Silva, D., \& Bido, D. (2014). Modelagem de equações estruturais com utilização do Smart PLS. ReMark, 13(2), 58-71.

Serviço Brasileiro de Apoio às Micro e Pequenas Empresas. (2015). Sebrae. Retrieved from www.sebrae.com

Stewart, S. A., Castrogiovanni, G. J., \& Hudson, B. A. (2016). A foot in both camps: Role identity and entrepreneurial orientation in professional service firms. International Journal of Entrepreneurial Behavior \& Research, 22(5), 718-744.
Victorino, L., Verma, R., Plaschka, F., \& Dev, C. (2005). Service innovation and customer choices in the hospitality industry. Management Service Quality, 15(6), 555-576.

Vij, S., \& Bedi, H. S. (2016). Are subjective business performance measures justified? International Journal of Productivity and Performance Management, 65(5), 603-621.

Wiklund, J., \& Shepherd, D. (2005). Entrepreneurial orientation and small business performance: A configurational approach. Journal of Business Venturing, 20(1), 71-89.

Yong, W., \& Panikkos, P. (2010). Entrepreneurial risk taking: Empirical evidence from UK family firms. International Journal of Entrepreneurial Behavior \& Research, 16(5), 370-388.

Zahra, S. A. (2005). Entrepreneurial risk taking in family firms. Journal of The Family Firm Institute, 18(1), 23-40.

Zattar, I., Silva, E., \& Silva, R. (2014). Desenvolvimento do Balanced Scorecard para uma empresa de fabricação de pontos de venda. XXI Simpósio de Engenharia de Produção.

Zeithaml, V. (2011). Marketing de serviços: A empresa com foco no cliente. Porto Alegre: Bookman.

Zhang, D. D., \& Bruning, E. (2011). Personal characteristics and strategic orientation: Entrepreneurs in Canadian manufacturing companies. International of entrepreneurial Behaviour \& Research, 17(1), 82-103. 